\title{
Influence Factors Psychological and Stigma During the Covid-19 Pandemic: Literature Review
}

\author{
Joko Susanto ${ }^{1}$, Moses Glorino Rumambo Pandin ${ }^{2}$ \\ ${ }^{1}$ Faculty of Nursing, Universitas Airlangga, Surabaya, Indonesia \\ ${ }^{2}$ English Department, Faculty of Humanities, Universitas Airlangga, Surabaya, Indonesia \\ Email: joko.susanto-2020@fkp.unair.ac.id, moses.glorino@fib.unair.ac.id
}

\begin{abstract}
Introduction: Corona Virus Disease 2019 causes health problems in the world in the form of a health crisis that results in psychological problems as fear and anxiety. The purpose of this study to determine the factors that influence psychological and stigma during the Covid-19 pandemic.

Methods: This study is a literature review with five databases (Scopus, CINAHL, ScienceDirect, PubMed, and ProQuest), studies design used a cross-sectional or quasiexperimental, with a date of March 2021. The Center for Review and Dissemination and the JBI Guide are used to measure the Quality and Prism checklist for guide reviews. A feasibility study based on title, abstract, full text, and research methodology. The data analysis used narrative analysis based on the research findings.

Results: Eleven articles met the predefined review inclusion criteria. Research is base on related factors psychology, related factors stigma, and factors related to psychological and stigma. Most of the factors associated with psychological conditions and stigma have a quasi-experimental and cross-sectional design. Participants averaged over a thousand for each study and discussed psychology factors related to the stigma.

Conclusion: Factors related to psychological are age, education, symptoms and health conditions, gender, information, economy, exposure duration, and social support, while factors related to stigma are environment, history of comorbid diseases, discrimination, and public perceptions.
\end{abstract}

Keyword: Psychological, Stigma, Covid-19

\section{INTRODUCTION}

Coronavirus Disease 2019 (Covid-19) disease caused by crisis health in the world, because of faster transmission and spread. The prevalence, mortality rate, risk transmission, and the absence is the drug, create fear and anxiety that will affect the psychological community. The psychological impact and social stigma of Covid-19 is caused by several factors, resulting in varying effects and reactions for each individual (1). The factors that affect the rejection of positive confirmed people and the bodies of Covid19 patients, because of the existence of members of the Covid-19 community is a dangerous disease and has a greats risk of being contagious, must keep away from the public. The negative stigma that arises will trigger psychological distress in both the patient and the community (2). However, the factors that influence psychological and stigma among the community still need to be deeply identified. 
Covid-19 pandemic as condition world health emergency continues to show a trend of increasing prevalence. Data on March 13, 2021, the prevalenced of Covid-19 in the world is 74.956 .790 cases, Indonesia, it reaches 1.414 .741 , with a death rate of 38,329 (3). A large number of unconfirmed information flows in various media causes people to become restless, fearful, and anxious (4). Results research in China psychology feeling afraid of Covid-19 is dangerous more than the disease (5). The Chinese population shows $53.8 \%$ experiencing severe psychological disorders, $16.5 \%$ major depression symptoms, $28.8 \%$ severe anxiety, and $8.1 \%$ severe stress (6). Facts in Indonesia show that there has been lots of rejection by the community towards Covid-19 patients and bodies because people consider Covid-19 to be very dangerous and have a high risk of transmitting and being dead that patient and corpses confirmed by Covid-19 must place far from residential areas (7).

In several reports in the mass media, information often appears about rejection and discrimination against people who have tested positive for Covid-19 and people who have close contact with Covid-19 patients, such as health workers. Negative stigma often occurs against health workers, for example, the expulsion of health workers from the boarding house or being refused to return home by the surrounding community, on the grounds of preventing the chain of transmission. The Covid-19 pandemic has turned into a problem that causes mass anxiety and paranoids $(8,9)$. Community reactions in the form of overprotection of oneself or family are caused by the symptom of compulsive obsession, anxiety, and fears $(4,10)$. Anxiety and fear in society have an impact on attitudes and actions of staying away from everyone so that in the end, discrimination and negative stigma will arise in society. The cause of this negative stigma is a lack of knowledge, information, anxiety, coping mechanisms, and support systems in society $(10,11)$.

The research in China showed that several factors that influence psychological disorders and stigma in society are gender, work experience, a history of psychological disorders, comorbid chronic diseases, and families with positive confirmed members (12). The research in South Korea also shows that education, marital status, and associate with psychological distress and stigma in Covid-19. Most of the existing studies still focus on the epidemiology and characteristics of Covid-19 patients $(13,14)$. There are not many studies that discuss the factors that influence psychological conditions and stigma in society. Therefore, necessary to conduct a literature review to identify the factor that influenced psychological and stigma. The aimed study to explain the factors that influence the psychological and stigma during the Covid-19 pandemic. 


\section{METHODS}

The research design is a literature review using the PRISMA checklist to determine the selection of studies that have been found and adjusted to the research objectives. The electronic database uses five databases, namely Scopus, ProQuest, Pubmed, CINAHL, and ScienceDirect.

Article searches use the Boolean Operator (AND, OR NOT or AND NOT), and keywords are adjusted to the Medical Subject Heading (MeSH) as follows:

Table 1 Keyword Literature Review

\begin{tabular}{llll}
\hline \multicolumn{1}{c}{ Factors } & \multicolumn{1}{c}{ Psychological } & \multicolumn{1}{c}{ Stigma } & \multicolumn{1}{c}{ COVID-19 } \\
\hline Risk factors & Psychological stress & Stigma & Corona Virus Disease 2019 \\
\hline OR & OR & OR & OR \\
\hline Factors & Mental health & Social Stigma & Wuhan Corona Virus \\
\hline OR & OR & & \\
\hline Causa & Mental disorder & & \\
\hline
\end{tabular}

Based on the results of a literature search on five databases, there were 267 articles. The search results have obtained were then check for duplication, found that there were 51 similar articles were excluded, and the remaining 216 articles. The researcher then conducted a screening based on the title $(n=216)$, abstract $(n=59)$, and full text $(n=11)$ adjusts to the theme of the literature review. The assessment carried out based on the eligibility of the inclusion and exclusion criteria obtained eleven articles used in the literature reviews.

Table 2 PICOS Format in Literature Review

\begin{tabular}{|c|c|c|}
\hline Kriteria & Inklusi & Ekslusi \\
\hline Population & $\begin{array}{l}\text { Studies on communities } \\
\text { affected Covid-19 }\end{array}$ & $\begin{array}{l}\text { Studies on communities not affected } \\
\text { Covid-19 }\end{array}$ \\
\hline Intervention & $\begin{array}{l}\text { Psychological and stigma } \\
\text { intervention }\end{array}$ & $\begin{array}{l}\text { Non-psychological and stigma } \\
\text { intervention }\end{array}$ \\
\hline Comparator & No comparator & - \\
\hline Outcomes & $\begin{array}{l}\text { Analysis of Factors Affecting } \\
\text { the Psychological and Stigma } \\
\text { During Covid-19 Pandemic }\end{array}$ & $\begin{array}{l}\text { Not Analysis of Factors Affecting } \\
\text { the Psychological and Stigma } \\
\text { During Covid-19 Pandemic }\end{array}$ \\
\hline $\begin{array}{l}\text { Study Design } \\
\text { And } \\
\text { Publication } \\
\text { Type }\end{array}$ & $\begin{array}{lr}\text { Cross-sectional, } & \text { Quasi- } \\
\text { experimental, } & \text { RCT, } \\
\text { qualitative } & \text { research, } \\
\text { systematic review } & \\
\end{array}$ & No exclusion \\
\hline $\begin{array}{l}\text { Publication } \\
\text { Years }\end{array}$ & Post 2019 & Pre 2019 \\
\hline Language & English, Indonesian & $\begin{array}{l}\text { Languages other than English and } \\
\text { Indonesian }\end{array}$ \\
\hline
\end{tabular}


The results of the study article selection can describe as follows:
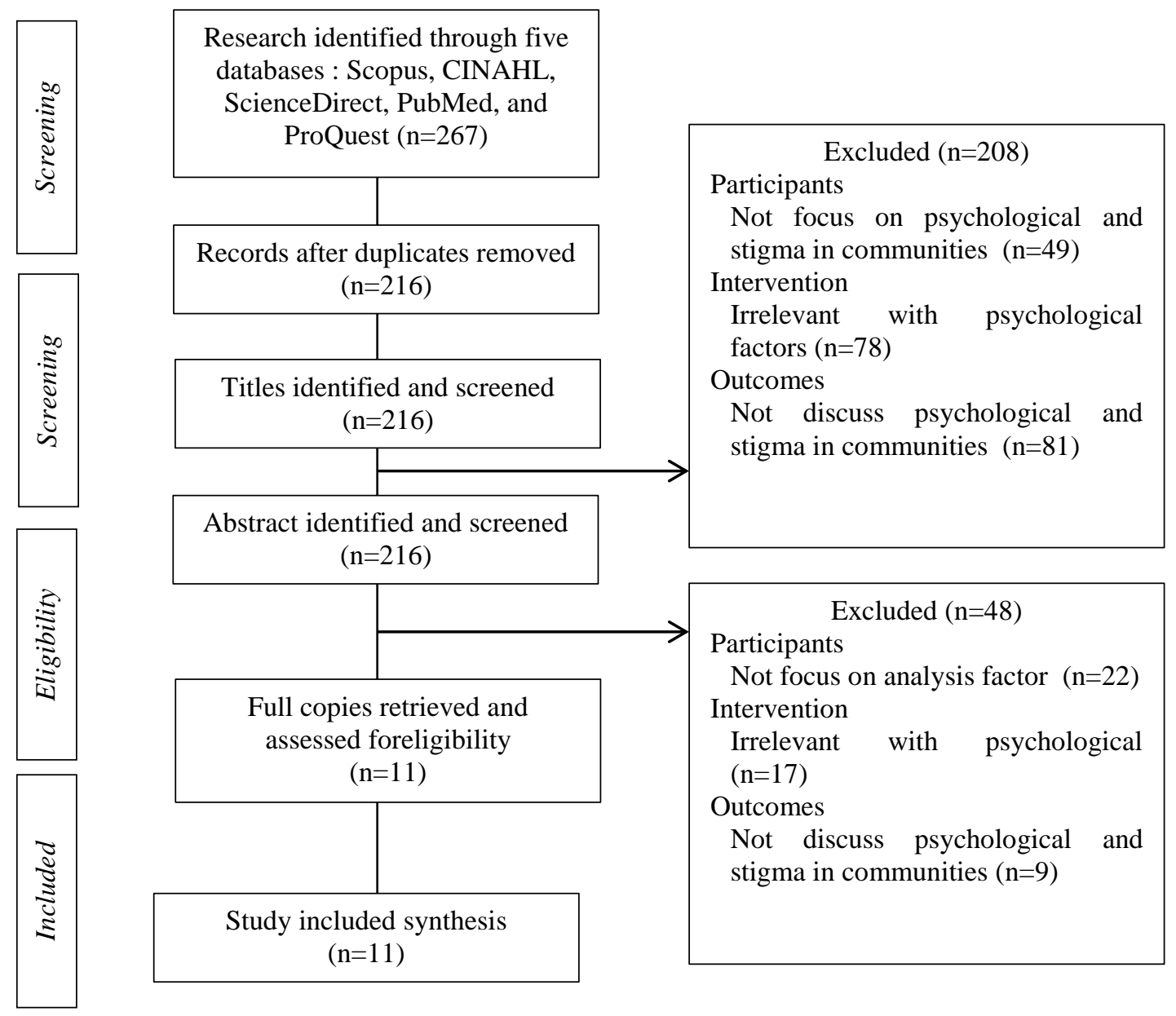

Figure 1 Article Search Algorithm in Literature Review

\section{RESULTS}

\section{Study Characteristics}

Eleven articles included criteria into two major themes, namely factors related to psychological (7 studies) and factors related to social stigma (3 studies), and 1 article relate to both. The factors that contribute to psychological and stigma are predominantly quasiexperimental and cross-sectional studies. Average participants mores thousand. The overalls studies addressed the psychological distress and associated factors with the stigma. The quality of studies is psychological, and the lowest is for stigma. Study the review mostly carried out in China as many as eight studies $(5,15,16)$, two studies conducted in South Korea (17,18) and 1 UK study (4). In particular, regarding Covid-19, the psychological is a factor that serious attention, because reported the psychological distress is dangerous more than the disease (19). The results of a study on seven studies show that the factors that influence psychology are: age, education, economy, gender, social support, history of chronic disease, and information. A review of three study factors that influence 
social stigma is community perception, experience, knowledge, educational background, and environmental stressors.

Table 3 Literature Search Results

\begin{tabular}{|c|c|c|c|}
\hline $\begin{array}{l}\text { Authors } \\
\text { and } \\
\text { Years }\end{array}$ & $\begin{array}{c}\text { Study design, Sample, } \\
\text { Variable, Instrument, } \\
\text { Analysis }\end{array}$ & $\begin{array}{c}\text { Outcome of } \\
\text { Analysis Factors }\end{array}$ & $\begin{array}{l}\text { Summary of } \\
\text { Results }\end{array}$ \\
\hline $\begin{array}{l}\text { (Jung and } \\
\text { Jun, } \\
\text { 2020) }\end{array}$ & $\begin{array}{l}\text { Design: Quasy-experimental } \\
\text { design } \\
\text { Sample: } 61 \text { patient (30 control } \\
\text { group and } 31 \text { intervention } \\
\text { group) } \\
\text { Variable: } \\
\text { counseling intervention from } \\
\text { The National Center for Mental } \\
\text { Health (NCMH) } \\
\text { Instrument: Questionnaire of } \\
\text { Social Support } \\
\text { Analysis: Mann Whitney and } \\
\text { Wilcoxon Signed Rank Test }\end{array}$ & $\begin{array}{lr}\text { Getting } & \text { reliable } \\
\text { information, } & \text { daily } \\
\text { life activities, social } \\
\text { networks, } \\
\text { experiences }\end{array}$ & $\begin{array}{l}\text { The common } \\
\text { problem affected } \\
\text { psychology } \\
\text { disorder was social } \\
\text { support Patient } \\
\text { will serched for } \\
\text { health services } \\
\text { during get illness }\end{array}$ \\
\hline $\begin{array}{l}\text { (Yang et } \\
\text { al., 2020) }\end{array}$ & $\begin{array}{l}\text { Design: Pre-experimental } \\
\text { design } \\
\text { Sample: } 241 \text { million older } \\
\text { adults in China } \\
\text { Variable: Mental health } \\
\text { services for older adults } \\
\text { Instrument: Observational } \\
\text { checklist for mental health } \\
\text { Analysis: Descriptive analysis }\end{array}$ & $\begin{array}{l}\text { Age, experience, } \\
\text { prevalence of } \\
\text { depression history }\end{array}$ & $\begin{array}{l}\text { Mental health } \\
\text { services for older } \\
\text { adults was needed } \\
\text { to increase mental } \\
\text { health in patients }\end{array}$ \\
\hline $\begin{array}{l}\text { (Jang et } \\
\text { al.,2018) }\end{array}$ & $\begin{array}{l}\text { Design: Cross-sectional design } \\
\text { Sample: } 13.269 \text { individual who } \\
\text { experince in depression } \\
\text { symptoms } \\
\text { Variable: Mental health, socio } \\
\text { demographic, socioeconomic } \\
\text { and health related factors } \\
\text { Instrument: Questionnaire of } \\
\text { Mental health, socio } \\
\text { demographic, socioeconomic } \\
\text { and health related factors } \\
\text { Analysis: Chi Square }\end{array}$ & $\begin{array}{l}\text { Educational } \\
\text { background, age, } \\
\text { gender and marital } \\
\text { status }\end{array}$ & $\begin{array}{l}\text { Consultation was } \\
\text { needed for older } \\
\text { adults, man, higher } \\
\text { education level and } \\
\text { divorced } \\
\text { maritalstatus }\end{array}$ \\
\hline $\begin{array}{l}\text { (Zhu et } \\
\text { al.,2020) }\end{array}$ & $\begin{array}{l}\text { Design: Cross-sectional design } \\
\text { Sample: } 5062 \text { respondent } \\
\text { Variable: Stress, depression } \\
\text { and anxiety impact during } \\
\text { pandemic. } \\
\text { Instrument: } \\
\text { Anxiety, Depression, Stress Score } \\
\text { Questionnaire } \\
\text { Analysis: Chi Square }\end{array}$ & $\begin{array}{l}\text { Stress level, age, } \\
\text { gender, years of } \\
\text { working experince, } \\
\text { chronic } \\
\text { family disease, } \\
\text { confirmed member } \\
\text { and mental disorder } \\
\text { history }\end{array}$ & $\begin{array}{l}\text { Women, higher } \\
\text { working } \\
\text { experience, history } \\
\text { of mental disorder, } \\
\text { chronic disease and } \\
\text { family confirmed } \\
\text { with suspected } \\
\text { criteria. }\end{array}$ \\
\hline
\end{tabular}




\begin{tabular}{|c|c|c|c|}
\hline $\begin{array}{l}\text { (Kang, } \\
\text { Ma, } \\
\text { Chen, } \\
\text { Yang } \\
\text { Wang, } \\
\text { Liand } \\
\text { Yao, } \\
2020)\end{array}$ & $\begin{array}{l}\text { Design: Cross-sectional design } \\
\text { Sample: 994 medical and } \\
\text { nursing staff in Wuhan } \\
\text { Variable: Mental health, } \\
\text { perception and psychological } \\
\text { care } \\
\text { Instrument: Mental health, } \\
\text { perception } \\
\text { psychological and } \\
\text { questionnaire } \\
\text { Analysis: Chi Square }\end{array}$ & $\begin{array}{l}\text { Expossure to disease, } \\
\text { counseling, age, } \\
\text { gender, } \\
\text { media for } \\
\text { information and } \\
\text { healthcare activity }\end{array}$ & $\begin{array}{lr}\text { There was still } \\
\text { lacking } & \text { of } \\
\text { psychological } & \\
\text { intervention } & \text { for } \\
\text { medical staff } & \end{array}$ \\
\hline $\begin{array}{l}\text { (Jiao et } \\
\text { al., 2020) }\end{array}$ & $\begin{array}{l}\text { Design: Cross-sectional design } \\
\text { Sample: 994 medical and } \\
\text { nursing staff in Wuhan } \\
\text { Variable: Mental health, } \\
\text { perception andpsychological } \\
\text { care } \\
\text { Instrument: Mental health, } \\
\text { perception andpsychological } \\
\text { care questionnairel } \\
\text { Analysis: Chi Square } \\
\text { age, gender,media for } \\
\text { informationand } \\
\text { healthcareactivityintervention } \\
\text { formedical staff }\end{array}$ & $\begin{array}{l}\text { Expossure to } \\
\text { disease, } \\
\text { counseling,age, } \\
\text { gender, media for } \\
\text { information and } \\
\text { healthcare activity }\end{array}$ & $\begin{array}{l}\text { There was still } \\
\text { lacking of } \\
\text { psychologicalinterv } \\
\text { ention for medical } \\
\text { staff }\end{array}$ \\
\hline $\begin{array}{l}\text { (Li et al., } \\
2020)\end{array}$ & $\begin{array}{l}\text { Design: Cross-sectional design } \\
\text { Sample: } 320 \text { children and } \\
\text { adolescents in China } \\
\text { Variable: The diagnostic and } \\
\text { statistical manual ofmental } \\
\text { disorders } \\
\text { Instrument: Demographic and } \\
\text { family supportquestionnaire } \\
\text { Analysis: Chi Square }\end{array}$ & $\begin{array}{l}\text { Age, epidemicarea } \\
\text { and } \\
\text { familysupporting }\end{array}$ & $\begin{array}{l}\text { Family supportwas } \\
\text { importantfactors to } \\
\text { improveresilience } \\
\text { inchildren } \\
\text { andadolescentdurin } \\
\text { g Covid-19 }\end{array}$ \\
\hline $\begin{array}{l}\text { (Ornell et } \\
a l ., 2020)\end{array}$ & $\begin{array}{l}\text { Design: Cross-sectional design } \\
\text { Sample: } 17.685 \text { active weibo } \\
\text { users } \\
\text { Variable: The approach of } \\
\text { online ecologicalrecognition } \\
\text { based on several machine } \\
\text { learningpredictive models } \\
\text { Instrument: Cognitive, support } \\
\text { system and lifesatisfaction } \\
\text { questionnaire } \\
\text { Analysis: Chi Square and } \\
\text { Logistic Regression }\end{array}$ & $\begin{array}{l}\text { Cognitive,supportsy } \\
\text { stem } \\
\text { andlifesatisfaction }\end{array}$ & $\begin{array}{l}\text { Individual } \\
\text { mayconcern } \\
\text { withtheir health } \\
\text { andfamilymembers } \\
\text { thisresults } \\
\text { willprovide datafor } \\
\text { governmentto fight } \\
\text { with Covid-19 }\end{array}$ \\
\hline $\begin{array}{l}\text { (Lai et } \\
\text { al., } \\
\text { 2020) }\end{array}$ & $\begin{array}{l}\text { Design: Cross-sectional design } \\
\text { Sample: } 1257 \text { health care } \\
\text { workers in China } \\
\text { Variable: Age, gender and } \\
\text { healthcare profession }\end{array}$ & $\begin{array}{l}\text { Age, genderand } \\
\text { healthcareprofession }\end{array}$ & $\begin{array}{l}\text { Psychologicalburd } \\
\text { en oftenfelt by } \\
\text { healthcareprofessio } \\
\text { nwhen they } \\
\text { givetreatment in }\end{array}$ \\
\hline
\end{tabular}




\begin{tabular}{|c|c|c|c|}
\hline & $\begin{array}{l}\text { Instrument: The 9-item patient } \\
\text { healthquestionnaire, the 7-item } \\
\text { insomnia severityindex, the 7- } \\
\text { iten generalized anxiety } \\
\text { disorderscale and the 22-item } \\
\text { impact of event to measure } \\
\text { distress, anxiety, insomniaand } \\
\text { depression } \\
\text { Analysis: Chi Square and } \\
\text { Logistic Regression }\end{array}$ & & Covid-19patients \\
\hline $\begin{array}{l}\text { (Yaguchi } \\
\text { and } \\
\text { Czeschli } \\
\mathrm{k} \text {, } \\
2010 \text { ) }\end{array}$ & $\begin{array}{l}\text { Design: Narative synthesis } \\
\text { Sample: } 24 \text { papers based on } \\
\text { inclussion criteria } \\
\text { Variable: Psychological and } \\
\text { social stigma responses }\end{array}$ & $\begin{array}{l}\text { Anxiety,depression, } \\
\text { anger, grief and loss, } \\
\text { stigmatization, } \\
\text { empowerment, } \\
\text { coping strategies and } \\
\text { social support }\end{array}$ & $\begin{array}{l}\text { Duringinfectious } \\
\text { disease, } \\
\text { psychological } \\
\text { intervention } \\
\text { become important } \\
\text { for public mental } \\
\text { health }\end{array}$ \\
\hline (15) & $\begin{array}{l}\text { Design: Cross-sectional design } \\
\text { Sample: } 7.236 \text { self volunteers } \\
\text { Variable: Age, gender, } \\
\text { occupation } \\
\text { healthcareworkers } \\
\text { Instrument: } \\
\text { Demographicquestionnaire,gen } \\
\text { eralized anxietydisorder, } \\
\text { Pittsburgh sleepquality index, } \\
\text { Center for epidemiologyscale } \\
\text { fordepression and Covid- } \\
\text { 19related knowledge } \\
\text { Analysis: Chi Square and } \\
\text { Logistic Regression }\end{array}$ & $\begin{array}{l}\text { Age, } \\
\text { gender,occupationan } \\
\text { d healthcareworkers }\end{array}$ & $\begin{array}{l}\text { The majormental } \\
\text { healthburden } \\
\text { inChina wereyoung } \\
\text { peopleand health } \\
\text { careworkers, becaus } \\
\text { e theywere in } \\
\text { highrisk } \\
\text { mentalillness for }\end{array}$ \\
\hline
\end{tabular}

\section{Psychological Affecting Factors}

1. Age

Age is a significant factor in the occurrence of depressive symptoms in the Chinese population. Age factor is closely related to depressive conditions 35 years or older, have a lower risk of experiencing depressive symptoms than age 35 years (18). Young participants ( $<35$ years) more likely to develop symptoms of depression and anxiety than the Covid-19 than older participants ( $\geq 35$ years) (2). These results differ from studies on psychology, shows a reported prevalence of depressive $23.6 \%$ in the population with mental health problems an older age in Chinese communities $(20,21)$.

2. Education

Education level has a positive relationship with regular mental health examinations and consultation (5). Low levels of education find to receive mental health consultation for depressive symptoms, also more frequent consultations than 
higher education levels (17). The status of the not education is associate with higher depressions and anxiety (15).

3. Gender

The female gender tends to score higher on the depressions and anxiety scale in line with women show higher rates of mental health consultations than men. Women have frequent consultations cause women to be more worried about facing illness (17). The results also show that anxiety is more severe and higher in women than men, find the study that women report more severe depression, anxiety, and distress (16).

4. Symptoms and Health Status

The results show myalgia, dizziness, cough, and throat were associated with higher depression and anxiety, and difficulty breathing was associated with anxiety and depression (22). Consultation and hospitalization at the clinic were associated with anxiety subscale scores. Poor health status was associated with a psychological (23).

5. Information Covid-19

Information increase in of recovered individuals was associated with lower stress score. The amount of information about drug and vaccine effectiveness, infections and location, and route transmission were associated with scores on the DASS anxiety (24). A high of concern for family members with confirmed Covid-19 is associated with a higher psychological. The young than 16 years of Covid-19 confirmation is associated with anxiety $(2,25)$.

6. Economy

Mental health services and psychological support and treatment strategy will directly improve economic and physical health because the cost and economic factors are related to mental disorders. Feelings of virus transmission, prognosis, and death have implications in other areas, closing schools, family organizations, companies, and the area public, isolation, changed work routines, caused feel of helplessness and neglect. Besides, increase insecurity to the economic and social impacts of larges tragedy and crisis (26).

7. Exposure Duration

Frontline workers experience psychological distress more than second-line workers, but considerable mental stress in workers in China. Workers in tertiary hospitals experience more severe symptoms of depression, anxiety, and insomnia than workers in secondary hospitals(27). Nurses who have to care for Covid-19 patients tend to be at higher risk of infection because they stay with patients is longer. The study also 
showed $71.5 \%$ of novice nurses, most of whom had little work experience (17).

8. Social Support

Problem psychological of a patient is the damage to the social support and social stigma of the patient. When a person avoids virus transmission, social support, schools, mosques, markets, and workplaces have closed, reduced, and eliminated the benefits of social support and can to feelings of isolation $(4,16)$. Therefore, the information by media important role in verified the validity of the public system. Mental health and society authorities must consistently and continuously eliminate stigma and improve social supports. Designing mental health care strategies for different population domains, including quarantined health workers be beneficial (18).

\section{Stigma Affecting Factors}

Negative stigma in the community occurs to rejection and isolation of the suspect, confirmed positively, with family and health workers. A large amount of information has impact negative stigma and rejection in society because society considers that every individual infected with Covid-19 should be avoided and shunned. If this problem is allowed to occur for a long time, it will cause psychological distress and caused the individual to become increasingly depressed and experience mental health problems $(15,17)$.

The form of stigma that comes from society takes the form of 1) Public stigma, namely the stigma caused by a community reaction to a family who has a disease or is at risk of transmitting it; 2) Structural stigma, namely the rejection of individuals in an institution or company due to virus transmission; 3) Self-stigma, namely decreased selfesteem and self-confidence due to illness; 4) Felt or perceived stigma, that is, a person feels there is a stigma against himself and is afraid to be in his community; (5) Experienced stigma, someone has experienced discrimination from other people; and 6) label avoidance, that is, someone does not participate in health services to avoid their status as a person who has a disease $(28,29)$.

The stigma of Covid-19 is triggered not only from individuals and individuals but also between society and individuals $(25,30)$. A person who has an infectious disease has the potential for rapid transmission and illness, resulting in discrimination against them. Feelings of feeling left out and isolated are often the result of past experiences about stigma and discrimination (17). The victim stated that he felt ostracized and alienated by his community, causing him to leave health services and distance himself from health workers 
(23). Isolation and quarantine procedures can be causes feel isolated, although the patient understands the need for quarantine measures caused will evoke enthusiasm and feel of abandonment that sometimes after discharge from the hospital (15). Quarantine procedures affect not has to expose the virus, as the new mother must separate from their children. Immigrants worry about the quarantine causes affecting the community and result from further isolation (22).

Education and knowledge are roles important in the incidence of stigma. Communities or individuals with high education backgrounds get more experience to transfers knowledge from the environment. In contrast to individuals with low educational backgrounds, they have a higher risk of giving a negative stigma to positive confirmed patients or their families. Health information is the factor that caused stigma because lack of information causes feelings of fear and thinks everyone will have the potential to transmit disease. Accurate and valid information can reduced stigma and preventing rapid transmission because correct information can increase people's knowledge $(4,28)$.

\section{DISCUSSION}

\section{Psychological Affecting Factors}

The prevalence of psychological distress Covid-19 increased every day, make someone afraid and worry about the transmission virus (16). Affect factors psychology and stigma of society consist of several, included internal and external factors. Influenced factors that psychological are age, education, gender, economy, social support, health status, and information. All factors influenced and caused psychological distress for society $(2,15)$.

Age is internally important caused depression. Some research results that most prone to experiences the incidence of depression are under 35 years, especial adolescents and early adulthood (12,18). Individuals under 35 years do not have experience and risk Covid-19 increase the contribute high risk of death. Over 55 years low symptom of depression because the elderly resign and wait for death causes need to preparedness peaceful death. Parents will be prepared for high spirituality when they have to leave the world $(17,25)$. The results women had a lower response to depression more than men because they more useless unable to provide a living and welfare for families. Men experience a decrease in self-esteem role of the head family does not go well. Physical distance makes men have work from home and caused income to decrease $(17,31)$. A higher-level education can accelerate adaptation and self-acceptance Covid-19. Good level 
knowledge makes it possible to select information accurate and valid, that feel minimally anxious and fearful $(15,23)$.

Decreased symptoms and health status, Covid-19 or the common cold, cause psychosomatic and increased stress $(18,32)$. Most people will be afraid to find signs and symptoms of Covid-19, even though not proven, only fatigue, flu, or weather. This condition caused attitudes and behaviors to carry out an examination and have thoughts about the effect experience. Can trigger the feeling of fear in the individual. Support from parties affects senses of comfort and calm individuals (26,32). The importance of motivation and support from friends, family, or the community will unite to fight Covid-19 and stop transmission. The pandemic has spread to all countries in the world to response participation of the community is needed to prevent and suppress high positive $(12,22)$.

\section{Stigma Affecting Factors}

The emergence of a negative social stigma due to Covid-19 causes a person to feel inadequate and worry about the transmission (16). Influence factors of negative stigma in society environment, history of comorbid diseases, discrimination, and public perceptions $(2,15)$. The stigma experienced by individuals in society to poor judgment and perception because accorded societies, anyone who is at risk of transmitting it will be considered dangerous and kept away from the environment $(4,28)$.

The negative stigma that has emerged in society rejects fear Covid-19. Many incidents reject restoring patients return to territory, family patients and health workers reject, and all individuals categorized as positive, suspicious, and surveillance (4). Often media reports and information well the absence of filtering of information to accept public, causing an increasingly panic condition. Collaboration and cooperation of all communities be a challenge in dealing with negative stigma $(30,31)$. Health education methods and strategies to done are corrected easy accepting (23). A limitation relates to the review of potential bias publications. Gray literature not carried out all peer-review articles in English included. Another limitation related to methodological, many use of pre-and postcontrolled study designs and the lack of a control group. The study was conducted not in all countries, only in the three countries with a greats prevalence.

\section{CONCLUSION}

Influence factors of psychological distress are age, education, gender, economy, social support, health status, and information. Influence factors of stigma are environment, 
history of comorbid diseases, discrimination, and public perceptions. Efforts to reduce psychological pressure and negative stigma Covid-19, which have not wide intervened, are to carry out further research to understand this phenomenon, to expected produced psychological interventions to deal with the Covid-19 pandemic impact.

\section{REFERENCES}

1. Cai H, Tu B, Ma J, Chen L, Fu L, Jiang Y, et al. Psychological impacts and coping strategies of front-line medical staff during COVID-19 outbreak in Hunan, China. Med Sci Monit [Internet]. 2020 Mar 23;26. Available from: https://www.medscimonit.com/abstract/index/idArt/924171

2. Yang Y, Li W, Zhang Q, Zhang L, Cheung T, Xiang Y-T. Mental health services for older adults in China during the COVID-19 outbreak. The Lancet Psychiatry [Internet]. 2020 Apr;7(4):e19. Available from: https://linkinghub.elsevier.com/retrieve/pii/S2215036620300791

3. Komite Nasional Penanganan Covid-19 dan Pemulihan Ekonomi. Situasi virus COVID-19 di Indonesia [Internet]. BNPB RI. 2021 [cited 2021 Mar 13]. Available from: https://covid19.go.id/

4. Kang L, Ma S, Chen M, Yang J, Wang Y, Li R, et al. Impact on mental health and perceptions of psychological care among medical and nursing staff in Wuhan during the 2019 novel coronavirus disease outbreak: A cross-sectional study. Brain Behav Immun [Internet]. $2020 \quad$ Jul;87:11-7. Available from: https://linkinghub.elsevier.com/retrieve/pii/S0889159120303482

5. Li S, Wang Y, Xue J, Zhao N, Zhu T. The Impact of COVID-19 Epidemic Declaration on Psychological Consequences: A Study on Active Weibo Users. Int J Environ Res Public Health [Internet]. 2020 Mar 19;17(6):2032. Available from: https://www.mdpi.com/1660-4601/17/6/2032

6. Qiu J, Shen B, Zhao M, Wang Z, Xie B, Xu Y. A nationwide survey of psychological distress among Chinese people in the COVID-19 epidemic: implications and policy recommendations. Gen Psychiatry [Internet]. 2020 Mar 6;33(2):e100213. Available from: http://gpsych.bmj.com/lookup/doi/10.1136/gpsych-2020-100213

7. Azanella LA. Penolakan Jenazah Pasien Covid-19, Mengapa Bisa Terjadi? Halaman all - Kompas.com. Kompas.com [Internet]. 2020 [cited 2021 Mar 25]; Available from: https://www.kompas.com/tren/read/2020/04/13/110821765/penolakan-jenazah-pasiencovid-19-mengapa-bisa-terjadi?page $=$ all

8. Catton H. Global challenges in health and health care for nurses and midwives everywhere. Int Nurs Rev [Internet]. 2020 Mar 21;67(1):4-6. Available from: https://onlinelibrary.wiley.com/doi/abs/10.1111/inr.12578

9. Manderson L, Levine S. COVID-19, Risk, Fear, and Fall-out. Med Anthropol [Internet]. 2020 Jul 3;39(5):367-70. Available from: https://www.tandfonline.com/doi/full/10.1080/01459740.2020.1746301

10. Liu C-Y, Yang Y, Zhang X-M, Xu X, Dou Q-L, Zhang W-W, et al. The prevalence and influencing factors in anxiety in medical workers fighting COVID-19 in China: a cross-sectional survey. Epidemiol Infect [Internet]. 2020 May 20;148:e98. Available from:

https://www.cambridge.org/core/product/identifier/S0950268820001107/type/journal_ article

11. Jiang F, Deng L, Zhang L, Cai Y, Cheung CW, Xia Z. Review of the Clinical Characteristics of Coronavirus Disease 2019 (COVID-19). J Gen Intern Med 
[Internet]. $2020 \quad$ May 4;35(5):1545-9. Available from: http://link.springer.com/10.1007/s11606-020-05762-w

12. Zhu Z, Xu S, Wang H, Liu Z, Wu J, Li G, et al. COVID-19 in Wuhan: Sociodemographic characteristics and hospital support measures associated with the immediate psychological impact on healthcare workers. EClinicalMedicine [Internet]. 2020 Jul;24:100443. Available from: https://linkinghub.elsevier.com/retrieve/pii/S2589537020301875

13. He F, Deng Y, Li W. Coronavirus disease 2019: What we know? J Med Virol [Internet]. 2020 Jul 28;92(7):719-25. Available from: https://onlinelibrary.wiley.com/doi/abs/10.1002/jmv.25766

14. Wu J, Feng CL, Xian XY, Qiang J, Zhang J, Mao QX, et al. [Novel coronavirus pneumonia (COVID-19) CT distribution and sign features]. Zhonghua Jie $\mathrm{He} \mathrm{He} \mathrm{Hu}$ Xi Za Zhi [Internet]. 2020 Mar 3 [cited 2021 Mar 11];43(0):E030. Available from: http://www.ncbi.nlm.nih.gov/pubmed/32125131

15. Huang Y, Zhao N. Generalized anxiety disorder, depressive symptoms and sleep quality during COVID-19 outbreak in China: a web-based cross-sectional survey. Psychiatry Res [Internet]. 2020 Jun;288:112954. Available from: https://linkinghub.elsevier.com/retrieve/pii/S0165178120306077

16. Lai J, Ma S, Wang Y, Cai Z, Hu J, Wei N, et al. Factors Associated With Mental Health Outcomes Among Health Care Workers Exposed to Coronavirus Disease 2019. JAMA Netw Open [Internet]. 2020 Mar 23;3(3):e203976. Available from: https://jamanetwork.com/journals/jamanetworkopen/fullarticle/2763229

17. Jang J, Lee SA, Kim W, Choi Y, Park E-C. Factors associated with mental health consultation in South Korea. BMC Psychiatry [Internet]. 2019 Dec 22;18(1):17. Available from: https://bmcpsychiatry.biomedcentral.com/articles/10.1186/s12888018-1592-3

18. Jung SJ, Jun JY. Mental Health and Psychological Intervention Amid COVID-19 Outbreak: Perspectives from South Korea. Yonsei Med J [Internet]. 2020;61(4):271. Available from: https://eymj.org/DOIx.php?id=10.3349/ymj.2020.61.4.271

19. Zhu Z, Xu S, Wang H, Liu Z, Wu J, Li G, et al. COVID-19 in Wuhan: Immediate psychological impact on 5062 Health Workers [Internet]. medRxiv. medRxiv; 2020 [cited 2021 Mar 11]. p. 2020.02.20.20025338. Available from: https://doi.org/10.1101/2020.02.20.20025338

20. Zu ZY, Jiang M Di, Xu PP, Chen W, Ni QQ, Lu GM, et al. Coronavirus Disease 2019 (COVID-19): A Perspective from China. Radiology [Internet]. 2020 Aug;296(2):E1525. Available from: http://pubs.rsna.org/doi/10.1148/radiol.2020200490

21. Yu H, Li M, Li Z, Xiang W, Yuan Y, Liu Y, et al. Coping style, social support and psychological distress in the general Chinese population in the early stages of the COVID-19 epidemic. BMC Psychiatry [Internet]. 2020 Dec 27;20(1):426. Available from: https://bmcpsychiatry.biomedcentral.com/articles/10.1186/s12888-020-02826-3

22. Yaguchi T, Czeschlik D. Narrative synthesis of psychological and coping responses towards emerging infectious disease outbreaks in the general population: practical considerations for the COVID-19 pandemic. Mycoscience [Internet]. 2019 Jan;51(1):1. Available https://linkinghub.elsevier.com/retrieve/pii/S1340354010701832

23. Oikarainen A, Mikkonen K, Kenny A, Tomietto M, Tuomikoski A-M, Meriläinen M, et al. Educational interventions designed to develop nurses' cultural competence: A systematic review. Int J Nurs Stud [Internet]. 2019;98:75-86. Available from: https://www.sciencedirect.com/science/article/pii/S0020748919301567

24. Wang C, Pan R, Wan X, Tan Y, Xu L, Ho CS, et al. Immediate Psychological Responses and Associated Factors during the Initial Stage of the 2019 Coronavirus 
Disease (COVID-19) Epidemic among the General Population in China. Int J Environ Res Public Health [Internet]. 2020 Mar 6;17(5):1729. Available from: https://www.mdpi.com/1660-4601/17/5/1729

25. Jiao WY, Wang LN, Liu J, Fang SF, Jiao FY, Pettoello-Mantovani M, et al. Behavioral and Emotional Disorders in Children during the COVID-19 Epidemic. J Pediatr [Internet]. 2020 Jun;221:264-266.e1. Available from: https://linkinghub.elsevier.com/retrieve/pii/S002234762030336X

26. Ornell F, Schuch JB, Sordi AO, Kessler FHP. "Pandemic fear" and COVID-19: mental health burden and strategies. Brazilian J Psychiatry [Internet]. 2020 Jun;42(3):232-5. Available from: http://www.scielo.br/scielo.php?script=sci_arttext\&pid=S151644462020000300232\&tlng=en

27. Luo M, Guo L, Yu M, Jiang W, Wang H. The psychological and mental impact of coronavirus disease 2019 (COVID-19) on medical staff and general public - A systematic review and meta-analysis. Psychiatry Res [Internet]. 2020 Sep;291:113190. Available from: https://linkinghub.elsevier.com/retrieve/pii/S0165178120310209

28. Corrigan PW, Bink AB. The Stigma of Mental Illness. In: Encyclopedia of Mental Health [Internet]. Elsevier; 2019. p. 230-4. Available from: https://linkinghub.elsevier.com/retrieve/pii/B9780123970459001701

29. Pedersen ER, Paves AP. Comparing perceived public stigma and personal stigma of mental health treatment seeking in a young adult sample. Psychiatry Res [Internet]. 2019 Sep;219(1):143-50. Available from: https://linkinghub.elsevier.com/retrieve/pii/S0165178114003886

30. Lancaster KE, Cernigliaro D, Zulliger R, Fleming PF. HIV care and treatment experiences among female sex workers living with HIV in sub-Saharan Africa: A systematic review. African J AIDS Res [Internet]. 2019 Dec 16;15(4):377-86. Available from: https://www.tandfonline.com/doi/full/10.2989/16085906.2016.1255652

31. Nursalam N, Sukartini T, Priyantini D, Mafula D, Efendi F. Risk Factors For Psychological Impact And Social Stigma Among People Facing Covid-19: A Systematic Review'. Syst Rev Pharmacy Medknow Publ. 2020;11(6):1022-8.

32. Torales J, O’Higgins M, Castaldelli-Maia JM, Ventriglio A. The outbreak of COVID19 coronavirus and its impact on global mental health. Int J Soc Psychiatry [Internet]. $2020 \quad$ Jun;66(4):317-20. Available
http://journals.sagepub.com/doi/10.1177/0020764020915212 from: 